\title{
Treatments of Çan Lignite with Some Mineral Acids after Sodyum Hydroxide Washing
}

\author{
Jale Gülen (Corresponding author), Sabriye Pişkin \& İbrahim Doymaz \\ Yildiz Technical University, Chemical Engineering Department, 34210, Davutpaşa, Istanbul, Turkey \\ Tel: 90-212-383-4754 E-mail: gulenj@yildiz.edu.tr
}

Received: March 24, 2011 Accepted: April 12, 2011 doi:10.5539/ijc.v3n3p75

\begin{abstract}
The fossil properties can be increased via enrichment process. It is the process that removes sulfur and mineral matter without changing the organic structure. In this study, Çan lignite was demineralized with some mineral free acid of $5 \%$ such as $\mathrm{HCOOH}$ and some mineral acids of $5 \%$ such as $\mathrm{HNO}_{3}, \mathrm{H}_{2} \mathrm{SO}_{4}, \mathrm{HCl}, \mathrm{H}_{3} \mathrm{PO}_{4}$ and $\mathrm{HF}$ after $5 \% \mathrm{NaOH}$ washing. The best sulfur and mineral matter performed were obtained with $\mathrm{NaOH}$ plus $\mathrm{HF}$ treatment as approximately $44 \%$ and $45 \%$, respectively. FTIR and X ray spectra of the samples were also drawn to determine the functional groups and mineral composition.
\end{abstract}

Keywords: Acid, Alkali, Lignite, Mineral matter, Sulfur

\section{Introduction}

Turkey has 8 billion lignite reserves. The estimated possible reserves are 30 billion tones. Although Turkey has such a big lignite reserves, most of them have low quality, high ash, volatile matter and sulfur ratio (Kaygusuz, 1997). Emissions of fossil fuel combustion are the major source of air pollution. The effect of this pollution on human health is a serious problem especially in the weather quality (Alonso, 2005).

The quality of fossil fuel is related to its structure. So, the mineral composition depend on the place, time and formation conditions (Sharma \& Gihar, 1991). The fossil fuels that have high mineral matter can be enriched applying for some chemicals.

For demineralization purposes; acidic, basic solutions or some chemicals such as peroxide, alcohol can be used (Kusakebe, et al., 1989). The carbonaceous parts are separated from the body. Later ash minerals are extracted and finally some elements such as (Na, K, Ca) in the organic body are leached (Yang, et al., 1985).

Several authors tried to extract those undesired parts in order to increase fossil quality. Chen et al tried the coal with some acids to remove the pyrite from HM lignite (bulianta coal mine, Shandong-China) and YZ bituminous coal (Yanzhou of Shandong-China). For this purpose, nitric acid and combination of hydrofluoric and hydrochloric acids were used. Although nitric acid is very effective for removing pyrite, it is also caluse slight oxidation of organic part of the coal. The total sulfur amounts of $\mathrm{HM}$ and $\mathrm{YZ}$ coals were 2.40 and 2.93 at the beginning. The sulfur ratios of $\mathrm{HF}$ treated coals were found as 2.00 and 2.95 . With $\mathrm{CrC}_{12} / \mathrm{HCl}$ application, those results were changed as 1.63 and 1.96 (Chen, et al., 1999).

Gulen et al studied some $5 \%$ and $10 \%$ acidic solutions of $\mathrm{HCl}, \mathrm{HNO}_{3}$ and $\mathrm{H}_{2} \mathrm{SO}_{4}$ for Silopi-Harput asphaltite. Maximum extraction degree of $40 \%$ was obtained with $\mathrm{HCl}$ acids of 5 and $10 \%$ (Gülen, et al., 2005).

Wang and his colleaques tested Australian coal with $\mathrm{Ca}(\mathrm{OH})_{2}$ plus $\mathrm{HCl}$ washing. They managed to extract $90 \%$ of the inorganic mater (Wang, et al., 1997).

Doymaz et al studied the combination of acid and alkali effects. They treated asphaltite with $\mathrm{NaOH}$ of $5 \%$ plus acids of $\mathrm{HNO}_{3}, \mathrm{HCl}, \mathrm{H}_{2} \mathrm{SO}_{4}$ of $10 \%$ and $\mathrm{HF}$ of $40 \%$. Approximately $60 \%$ extraction was performed with $5 \%$ $\mathrm{NaOH}$ plus $10 \% \mathrm{H}_{2} \mathrm{SO}_{4}$ and $40 \% \mathrm{HF}$ acids (Doymaz, et al., 2007).

Murkherjee and Borthakur leached Assam coal in India with $\mathrm{NaOH}$ followed $\mathrm{HCl}$ treatment. They managed to extract approximately $50 \%$ ash and inorganic sulfur and $10 \%$ of organic sulfur (Mukherjee \& Borthakur, 2003).

Steel and Patrick studied the HF acid alone and $\mathrm{HF}$ and $\mathrm{HNO}_{3}$ together for UK coal. The ash level was decreased from $7.90 \%$ to $2.6 \%$ with $\mathrm{HF}$ alone and from $2.8 \%$ to $0.6 \%$ with $3.51 \mathrm{M} \mathrm{HF}$ and $1.26 \mathrm{M} \mathrm{HNO}_{3}$ together (Steel \& Patrick, 2001). 
In this study, Çan lignite was treated with $5 \% \mathrm{NaOH}$ plus $5 \% \mathrm{HNO}_{3}, \mathrm{HCOOH}, \mathrm{H}_{2} \mathrm{SO}_{4}, \mathrm{HCl}, \mathrm{H}_{3} \mathrm{PO}_{4}$ and $\mathrm{HF}$ acids for removing undesired parts.

\section{Experimental}

\subsection{Materials}

The materials have been grounded and sieved to pass $0.250 \mu \mathrm{m}$ sieve. The proximate analysess are shown in Table 1. Those analyses were suite with ASTM standards (ASTM, 1983).

\subsection{Methods}

The high sulfur amount of Çan lignite was tried to decrease with basic $5 \% \mathrm{NaOH}$ and later some $5 \%$ acidic solutions. These concentrations were chosen being studied at very diluted medium. $4 \mathrm{~g}$ lignite samples were stirred with $5 \% \mathrm{NaOH}$ solution for 20 minutes. This sample was filtered, washed hot distilled water and dried in the oven at $105^{\circ} \mathrm{C}$. Later, dried samples were stirred the aqueous acidic solutions for 20 minutes, filtered, washed and dried in the oven. Total sulfur amount of Çan lignite was found as $3.80 \%$. The sulfatic, pyritic and organic ones were $0.75 \%, 1.03 \%, 2.02 \%$, respectively. The sulfur results of Çan lignite treated with chemical agents are seen in Table 2.

Mineral matter of Çan lignite was decreased by applying 5\% acidic solutions after affecting 5\% alkali solution. Table 3 shows the ash values for demineralized samples.

The varitions in caloriific values after treated with those chemicals are shown in Table 4.

FTIR and Xray spectra of original and chemical treated samples were also drawn with Perkin Elmer and Rigaku Xray spectrometers, respectively. FTIR tablets were at the ratio of 1:100 (w/w) fuel and $\mathrm{KBr}$. X ray difraction pattern were collected at $0-70^{\circ} 2 \theta$.

Figure 1 and 2 show the FTIR and Xray spectra of Çan and chemical treated samples.

\section{Results and Discussion}

The results indicate that maximum sulfur reduction was obtained with $5 \% \mathrm{NaOH}$ plus $5 \% \mathrm{HF}$ as $43.95 \%$ yield (Table 2). The second best result was found with $\mathrm{H}_{3} \mathrm{PO}_{4}$ treatments as $32 \%$ sulfur removal. HF was very effective for decreasing mineral parts from the body. The result was $44.48 \%$ yield (Table 3 ). The second important agent was $\mathrm{HCl}$. It is suggested that smaller molecules can more easily diffuse into particle according to Sharma and Gihar. So, $43.60 \%$ demineralization was performed with $\mathrm{HCl}$ treatment. Aqueous $\mathrm{H}_{3} \mathrm{PO}_{4}$ acid was supplied for $22.50 \%$ demineralization result.

Figure $1(\mathrm{a}, \mathrm{b})$ shows the functional structure of Çan and chemical treated samples as FTIR spectra. The samples were sequenced from bottom to top as original (A), $\mathrm{NaOH}(\mathrm{B}), \mathrm{H}_{3} \mathrm{PO}_{4}(\mathrm{C}), \mathrm{HCOOH}(\mathrm{D}), \mathrm{HNO}_{3}(\mathrm{E}), \mathrm{H}_{2} \mathrm{SO}_{4}(\mathrm{~F})$, $\mathrm{HCl}(\mathrm{G})$ and $\mathrm{HF}(\mathrm{H})$ treated.

In the original spectrum, the peaks at $474,536,598,801 \mathrm{~cm}^{-1}$ show the mineral matter of lignite. These areas are thr areas of print finger and those peaks cannot be determined separately. And those peaks the evidence of mineral matter existence. 1033, 1097, 1122, $1199 \mathrm{~cm}^{-1}$ bands are due to C-O stretching. $1401,1435 \mathrm{~cm}^{-1}$ also represent etheric oxygen group. 1401, $1435 \mathrm{~cm}^{-1}$ which is a smaller shoulder peak and $1619 \mathrm{~cm}^{-1}$ bands are aromatic $\mathrm{C}=\mathrm{C}$ and $\mathrm{C}=\mathrm{O}$ stretching. Aliphatic $\mathrm{C}-\mathrm{H}$ groups give absorbance at $2846 \mathrm{~cm}^{-1} .2923 \mathrm{~cm}^{-1}$ show the presence of $\mathrm{CH}_{3}$ and $\mathrm{CH}_{2}$ groups in the body. $3395 \mathrm{~cm}^{-1}$ peak is the indicator of $\mathrm{O}-\mathrm{H}$ stretching. Beyond 3500 $\mathrm{cm}^{-1}$, it is possible to expect the clay mineral existence.

After $\mathrm{NaOH}$ washing, the peak heights which show mineral matter eistence are decreased.

Peaks at $1011,1106 \mathrm{~cm}^{-1}$ show C-O stretching. The bands at 1270, 1380, $1570 \mathrm{~cm}^{-1}$ are C-O stretching, etheric oxygen and asymetric symetric carboxyl groups, respectively. The sharp end at $1400 \mathrm{~cm}^{-1}$ which indicate $\mathrm{C}=\mathrm{C}$ stretching was decreased after alkali washing.

Leaching with $\mathrm{H}_{3} \mathrm{PO}_{4}$, some mineral parts were removed. Peaks appeared at $468,532 \mathrm{~cm}^{-1}$ show mineral structure. C-O stretching bands are seen at $1034,1111,1270,1610 \mathrm{~cm}^{-1} .1401$ and $1610 \mathrm{~cm}^{-1}$ are for $\mathrm{C}=\mathrm{C}$ and $\mathrm{C}=\mathrm{O}$ stretching, respectively. The peak of aliphatic $\mathrm{C}-\mathrm{H}$ group at $3153 \mathrm{~cm}^{-1}$ was rounded with $\mathrm{H}_{3} \mathrm{PO}_{4}$ leaching.

With $\mathrm{HCOOH}$ effect, the peaks at $471,528 \mathrm{~cm}^{-1}$ were mineral matter. Bands shown at $1032,1114 \mathrm{~cm}^{-1}$ are $\mathrm{C}-\mathrm{O}$ stretching. The double peaks at $1400 \mathrm{~cm}^{-1}$ are aromatic $\mathrm{C}=\mathrm{C}$ stretching. $\mathrm{C}=\mathrm{O}$ stretching peak was shown at 1608 $\mathrm{cm}^{-1}$. Peaks at $2841,2921 \mathrm{~cm}^{-1}$ are seen due to aliphatic $\mathrm{C}-\mathrm{H}$ group and $\mathrm{CH}_{3} / \mathrm{CH}_{2}$ groups, respectively. Aliphatic $\mathrm{C}-\mathrm{H}$ group at $3192 \mathrm{~cm}^{-1}$ gives a wider shoulder peak.

With $\mathrm{HNO}_{3}$ treatment, peaks seen at 536, 821, 872, 911 are due to mineral matter. C-O stretching peaks at 1384 
$\mathrm{cm}^{-1}$ was increased. The peak at $1603 \mathrm{~cm}^{-1}$ was decreased. $2841,2921,3153$ peaks are aliphatic $\mathrm{C}-\mathrm{H}, \mathrm{CH}_{3} / \mathrm{CH}_{2}$ groups and aliphatic $\mathrm{C}-\mathrm{H}$ groups, respectively.

With $\mathrm{H}_{2} \mathrm{SO}_{4}$ acid extraction, the peaks which indicate mineral matter was very small. 1034,1280 and $1598 \mathrm{~cm}^{-1}$ peaks show $\mathrm{C}-\mathrm{O}$ stretching and $\mathrm{C}=\mathrm{O}$ stretching. $2841,2920,3178 \mathrm{~cm}^{-1}$ peaks are similar the spectrum of $\mathrm{HNO}_{3}$.

When $\mathrm{HCl}$ was applied, the peaks at $466,540,793 \mathrm{~cm}^{-1}$ show mineral parts of lignite. $1032,1114,1263 \mathrm{~cm}^{-1}$ bands are $\mathrm{C}-\mathrm{O}$ stretching. The peaks at 1401 and $1607 \mathrm{~cm}^{-1}$ show $\mathrm{C}=\mathrm{C}$ stretching and $\mathrm{C}=\mathrm{O}$ stretching. 2841, 2921, 3153 peaks are aliphatic $\mathrm{C}-\mathrm{H}, \mathrm{CH}_{3} / \mathrm{CH}_{2}$ group, aliphatic $\mathrm{C}-\mathrm{H}$ group, respectively.

With HF washing, a sharp peaks at 483 and $741 \mathrm{~cm}^{-1}$ and a small one at $590 \mathrm{~cm}^{-1}$ are mineral parts. Bands seen at 1275,1396 and $1608 \mathrm{~cm}^{-1}$ show $\mathrm{C}-\mathrm{O}$ stretching. 1438 and $1608 \mathrm{~cm}^{-1}$ bands are aromatic $\mathrm{C}=\mathrm{C}$ and $\mathrm{C}=\mathrm{O}$ groups, respectively.

Figure 2 (a b) show the Xray spectra of Çan and other chemical treated samples. The bottom spectrum was original Çan lignite (A). The others were $\mathrm{NaOH}(\mathrm{B}), \mathrm{HNO}_{3}$ (C), $\mathrm{H}_{2} \mathrm{SO}_{4}$ (D), $\mathrm{HCl}(\mathrm{E}), \mathrm{H}_{3} \mathrm{PO}_{4}$ (F), $\mathrm{HF}(\mathrm{G})$, $\mathrm{HCOOH}(\mathrm{H})$ treated samples from bottom to top.

The original Çan lignite gave peaks at $2 \theta=13.780,23.099,34.200$ as Nesquhomite; $2 \theta=23.962,33.162,40.858$, $43.436,49.498,54.158,62.522$ as hematite; $2 \theta=24.521,31.338,38.582,52.352,57.717$ as anhydride groups.

With $\mathrm{NaOH}$ treatment, quartz and hematite groups left. Thety gave peaks at $2 \theta=20.882,26.661,39.517,40.438$, $45.837,50.194,59.998,64.201,67.877,68.342,75.664$ and $2 \theta=24.184,33.181,35.682,40.960,43.537,49.557$, $54.178,57.701,62.514$, respectively.

When we applied $\mathrm{HNO}_{3}$ acids those groups were found at the following. The peaks at $2 \theta=20.664,26.700$, $36.616,42.556,50.142,60.033,64.216,67.818,68.421$ quartz ones, $2 \theta=24.331,33.258,35.737,41.074,49.659$, $54.162,62.697$ hematite groups and $2 \theta=21.318,23.162,28.156,29.720,38.463$ gerdonite minerals.

The peaks at $2 \theta=24.578,28.716,31.396,40.878,43.281,59.038$ were due to anhydride groups after $\mathrm{H}_{2} \mathrm{SO}_{4}$ treatment. Also, ternardite gave peaks at $2 \theta=19.074,23.123,28.037,32.139,35.696,38.519,48.839,49.462$.

With $\mathrm{HCl}$ washing, the peaks shown at $2 \theta=20.919,26.664,36.561,39.502,42.502,45.841,50.217,60.001$ and $2 \theta=24.235,33.221,35.663,49.501,54.261,62.519$ correspond to quartz and hematite groups, respectively.

With $\mathrm{H}_{3} \mathrm{PO}_{4}$ leaching, the peaks at $2 \theta=20.318,21.659,22.656,28.894,30.745,35.954,39.517,50.237$ and $2 \theta$ $=20.824,26.642,36.576,42.476,59.943,67.724,68.314$ suite nacrite and quartz groups, respectively.

HF is very effective for clay especially siliceaus minerals. Amesite, fluorite and williamite groups in the body gave peaks at $2 \theta=21.258,25.579,35.600,52.597 ; 2 \theta=28.315,33.019,47.019,68.658,87.400 ; 2 \theta=38.862$, $56.139,70.376,83.417$, respectively.

The top spectrum shows the HCOOH effect on the lignite body. The peaks at $2 \theta=23.804,26.582,36.534,50.118$, $55.460,59.929,64.077,68.219$ were quartz; $2 \theta=21.240,23.136,24.149$ chalcoalumite and $2 \theta=30.362,43.497$, $54.120,57.639$ were magnesiochromite groups.

\section{Conclusions}

In this study, chemical treatment of Çan lignite was performed with aqueous acids of $\mathrm{HNO}_{3}, \mathrm{HCOOH}, \mathrm{H}_{2} \mathrm{SO}_{4}$, $\mathrm{HCl}, \mathrm{H}_{3} \mathrm{PO}_{4}$ and $\mathrm{HF}$ after alkali $\mathrm{NaOH}$ treatment. $5 \% \mathrm{HF}$ is given the best result from the removal of sulfur and mineral parts. The enrichment yields were approximately $44 \%$ (Table 2, 3). Maximun calorific increament was found in $\mathrm{HCl}$ treatment as $12 \%$ (Table 4). The result of $\mathrm{HF}$ acid was $7 \%$. Çan lignite has some organic constituents which is seen from $\mathrm{C}-\mathrm{H}$ and $\mathrm{C}=\mathrm{O}$ stretching vibrations of FTIR spectra. Original Çan lignite has some mineral groups such as hematite, anhydride, quartz, ternardite, nacrite, etc. Xray spectra show these mineral groups being left after demineralization treatment.

\section{References}

Alonso, T. (2005). A new perspective about recovering $\mathrm{SO}_{2}$ groups in coal power plants: Energy saving. Part III. Selection at the best method. Energy Sources, vol. 27, pp.1051-1060. [Online] Available: http://dx.doi.org/10.1080/00908310490479204.

American society for testing and materials. Annual book of ASTM standards. (1983). Part 26, (Methods D 2015, D 2072, D 3174 and D 3177). Philadelphia, PA, USA.

Chen, H., Li, B., Zhang, B. (1989). The effect of acid teratment on the removal of pyrite in coal. Fuel, vol. 78, pp.1237-1238. [Online] Available: http://www.elsevier.com/locate/fuel.

Doymaz, I., Gülen, J., Pişkin, S., Toprak, S. (2007). The effect of aqueous and various acid treatments on the 
removal of mineral matter in asphaltite. Energy Sources, vol. 29, pp.337-346. doi: 10.1080/15567030600819882, http://dx.doi.org/10.1080/15567030600819882.

Gülen, J., Doymaz, I., Toprak, S., Pişkin, S. (2005). Removal of mineral matter from Silopi-Harput asphaltite by various acid treatment. Energy Sources, vol. 27, pp.1457-1464. doi: 10.1080/009083190523307, http://dx.doi.org/10.1080/009083190523307.

Kaygusuz, K. (1997). Energy, water and environment in Turkey. Energy Sources, vol. 19, pp.917-930. doi: 10.1080/00908319708908901, http://dx.doi.org/10.1080/00908319708908901.

Kusakebe, K., Orita, K., Kato, S, Morooko, Y. and Kato, K. (1989). Simultaneous desulphurization and demineralization of coal. Fuel, vol. 68, pp.396-399.

Mukherjee, S., Borthakur, P. C. (2003). Demineralization of subbituminous high sulfur coal using mineral acids. Fuel Processing Terchnology, vol 85, pp.157-164. doi:10.1016/50378-3820(03)00140-1, http://dx.doi.org/10.1016/50378-3820(03)00140-1.

Sharma, D. K. and Gihar, C. (1991). Chemical cleaning of low grade coals through alkali-asit leaching employing mild conditions under ambient pressure. Fuel, vol. 70, pp.663-665.

Steel, K. M. and Patrick, S. W. (2001). The production of ultra clean coal by chemical demineralization. Fuel, vol. 80, pp.2019-2023.

Wang, J., Tomita, A., Taylor, G. H. and Fitz Gerald, J. D. (1997). Microscopic observation of coal demineralization by $\mathrm{Ca}(\mathrm{OH}) 2$ leaching. Fuel, vol. 76, pp.369-374.

Yang, R. T., Das Subho, K. and Tsai, M. C. (1985). Coal demineralization using sodium hydroxide and acid solutions. Fuel, vol. 64, pp.735-742.

Table 1. Proximate analyses of Çan lignite

\begin{tabular}{|c|c|}
\hline Fixed carbon $\%$ & 64.81 \\
\hline Volatile matter \% & 28.08 \\
\hline Sulfur \% & 3.80 \\
\hline Ash $\%$ & 7.11 \\
\hline Moisture $\%$ & 10.70 \\
\hline Calorific value & $22402 \mathrm{~kJ} / \mathrm{kg}$ \\
\hline
\end{tabular}

Table 2. Sulfur variation values of Can lignite and chemical treated samples

\begin{tabular}{|c|c|c|}
\hline Sample & NaOH 5 \% & Sulfur removal \% \\
\hline Çan $(\mathrm{A})$ & 3.09 & 18.68 \\
\hline$(\mathrm{A})+\mathrm{HNO}_{3}$ & 3.73 & 1.84 \\
\hline$(\mathrm{A})+\mathrm{HCOOH}$ & 2.98 & 21.58 \\
\hline$(\mathrm{A})+\mathrm{H}_{2} \mathrm{SO}_{4}$ & 2.89 & 25.0 \\
\hline$(\mathrm{A})+\mathrm{HCl}$ & 2.66 & 30.0 \\
\hline$(\mathrm{A})+\mathrm{H}_{3} \mathrm{PO}_{4}$ & 2.57 & 32.37 \\
\hline$(\mathrm{A})+\mathrm{HF}$ & 2.13 & 43.95 \\
\hline
\end{tabular}

Table 3. Ash removal and demineralization variations of Can lignite and chemical treated samples

\begin{tabular}{|c|c|c|}
\hline Sample & NaOH 5 \% & Demineralization \% \\
\hline Çan (A) & 6.58 & 7.45 \\
\hline$(\mathrm{A})+\mathrm{H}_{3} \mathrm{PO}_{4}$ & 5.51 & 22.50 \\
\hline$(\mathrm{A})+\mathrm{HCOOH}$ & 5.1 & 28.27 \\
\hline$(\mathrm{A})+\mathrm{HNO}_{3}$ & 4.48 & 36.99 \\
\hline$(\mathrm{A})+\mathrm{H}_{2} \mathrm{SO}_{4}$ & 4.36 & 38.68 \\
\hline$(\mathrm{A})+\mathrm{HCl}$ & 4.01 & 43.60 \\
\hline$(\mathrm{A})+\mathrm{HF}$ & 3.94 & 44.48 \\
\hline
\end{tabular}


Table 4. Calorific values of Can Lignite and chemical treated samples

\begin{tabular}{|c|c|c|}
\hline Sample & $\mathrm{NaOH}(\mathrm{kJ} / \mathrm{kg})$ & Variation in calorific value $\%$ \\
\hline Çan $(\mathrm{A})$ & 22401.6 & -- \\
\hline$(\mathrm{A})+\mathrm{H}_{3} \mathrm{PO}_{4}$ & 23354.6 & 4.2 \\
\hline$(\mathrm{A})+\mathrm{HCOOH}$ & 23532.6 & 5.04 \\
\hline$(\mathrm{A})+\mathrm{H}_{2} \mathrm{SO}_{4}$ & 23709.9 & 5.8 \\
\hline$(\mathrm{A})+\mathrm{HF}$ & 24059.6 & 7.4 \\
\hline$(\mathrm{A})+\mathrm{HNO}$ & 25036.2 & 11.8 \\
\hline$(\mathrm{A})+\mathrm{HCl}$ & 25159.2 & 12.3 \\
\hline
\end{tabular}

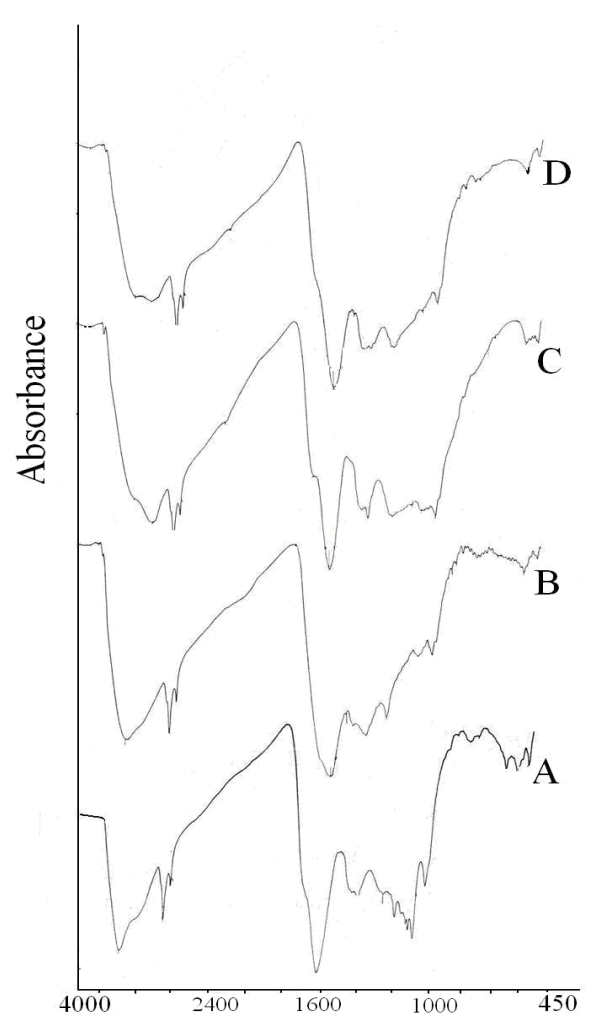

Wave numbers $\mathrm{cm}-1$

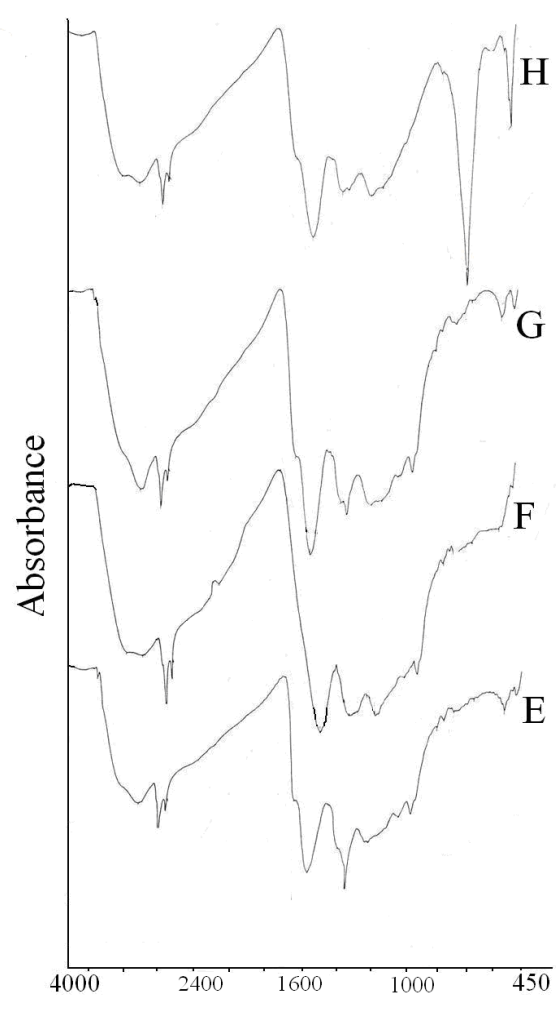

Wave numbers $\mathrm{cm}-1$

Figure 1 (a)

Figure 1 (b)

Figure 1. (a, b) FTIR spectra of Çan lignite and other chemical treated samples $\left(\mathrm{A}=\right.$ Original Çan lignite, $\mathrm{B}=(\mathrm{A})+5 \% \mathrm{NaOH}(\mathrm{B}), \mathrm{C}=(\mathrm{A})+(\mathrm{B})+5 \% \mathrm{H}_{3} \mathrm{PO}_{4}, \mathrm{D}=(\mathrm{A})+(\mathrm{B})+5 \% \mathrm{HCOOH}$, $\left.\mathrm{E}=(\mathrm{A})+(\mathrm{B})+5 \% \mathrm{HNO}_{3}, \mathrm{~F}=(\mathrm{A})+(\mathrm{B})+5 \% \mathrm{H}_{2} \mathrm{SO}_{4}, \mathrm{G}=(\mathrm{A})+(\mathrm{B})+5 \% \mathrm{HCl}, \mathrm{H}=(\mathrm{A})+(\mathrm{B})+5 \% \mathrm{HF}\right)$. 


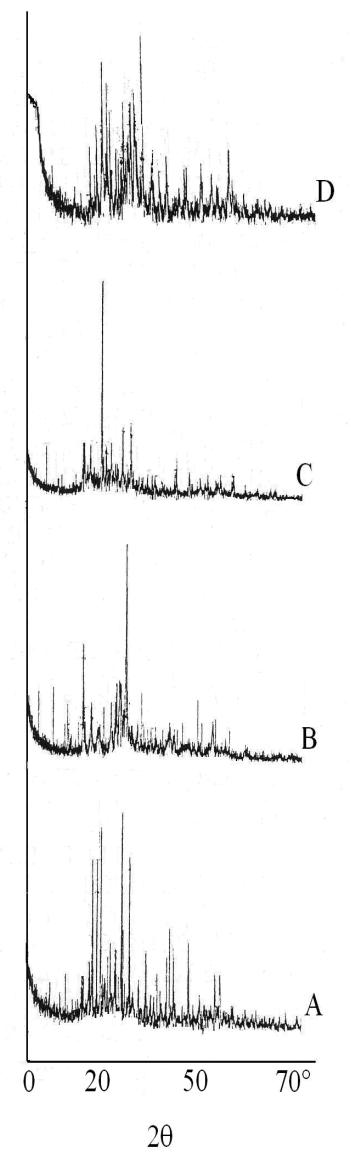

Figure 2 (a)

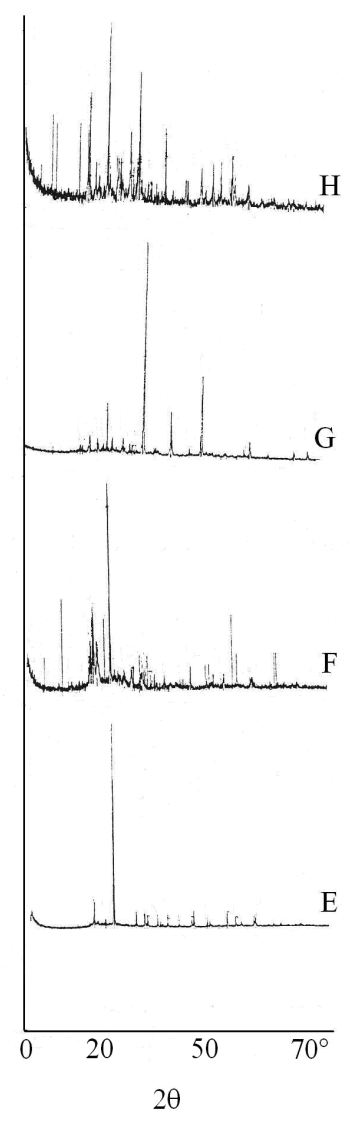

Figure 2. (b)

Figure 2. $(a, b) X$ ray spectra of Çan lignite and other chemical treated samples $\left(\mathrm{A}=\right.$ Original Çan lignite, $\mathrm{B}=(\mathrm{A})+5 \% \mathrm{NaOH}(\mathrm{B}), \mathrm{C}=(\mathrm{A})+(\mathrm{B})+5 \% \mathrm{HNO}_{3}, \mathrm{D}=(\mathrm{A})+(\mathrm{B})+5 \% \mathrm{H}_{2} \mathrm{SO}_{4}$, $\left.\mathrm{E}=(\mathrm{A})+(\mathrm{B})+5 \% \mathrm{HCl}, \mathrm{F}=(\mathrm{A})+(\mathrm{B})+5 \% \mathrm{H}_{3} \mathrm{PO}_{4}, \mathrm{G}=(\mathrm{A})+(\mathrm{B})+5 \% \mathrm{HF}, \mathrm{H}=(\mathrm{A})+(\mathrm{B})+5 \% \mathrm{HCOOH}\right)$. 